\title{
The Importance of Zebrafish in Biomedical Research
}

\author{
A Importância do Peixe-Zebra na Investigação Biomédica
}

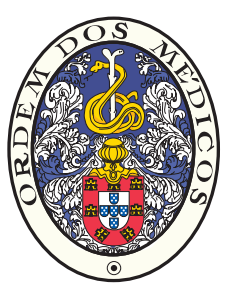

\author{
Bárbara TAVARES ${ }^{1}$, Susana SANTOS LOPES ${ }^{1}$ \\ Acta Med Port 2013 Sep-Oct;26(5):583-592
}

\section{ABSTRACT}

Introduction: Zebrafish (Danio rerio) is an ideal model organism for the study of vertebrate development. This is due to the large clutches that each couple produces, with up to 200 embryos every 7 days, and to the fact that the embryos and larvae are small, transparent and undergo rapid external development.

Material and Methods: Using scientific literature research tools available online and the keywords Zebrafish, biomedical research, human disease, and drug screening, we reviewed original studies and reviews indexed in PubMed.

Results: In this review we summarized work conducted with this model for the advancement of our knowledge related to several human diseases. We also focused on the biomedical research being performed in Portugal with the zebrafish model.

Discussion: Powerful live imaging and genetic tools are currently available for zebrafish making it a valuable model in biomedical research. The combination of these properties with the optimization of automated systems for drug screening has transformed the zebrafish into "a top model" in biomedical research, drug discovery and toxicity testing. Furthermore, with the optimization of xenografts technology it will be possible to use zebrafish to aide in the choice of the best therapy for each patient.

Conclusion: Zebrafish is an excellent model organism in biomedical research, drug development and in clinical therapy.

Keywords: Biomedical Research; Disease Models, Animal; Drug Evaluation, Preclinical; Zebrafish.

\section{RESUMO}

Introdução: O peixe-zebra (Danio rerio) é um excelente organismo modelo para o estudo do desenvolvimento dos vertebrados. Este facto deve-se à produção de grandes posturas, que podem atingir 200 embriões a cada sete dias, e ao facto dos embriões serem pequenos, transparentes e com um rápido desenvolvimento externo.

Material e Métodos: Usando ferramentas de pesquisa bibliográfica científica disponíveis online e utilizando as palavras-chave "Zebrafish", "biomedical research", "human disease" e "drug screening", avaliámos estudos originais e revisões indexadas na PubMed.

Resultados: Neste artigo de revisão fazemos um resumo do trabalho realizado com este modelo no melhoramento do conhecimento de várias doenças humanas. Fizemos ainda um breve relato da investigação biomédica realizada em Portugal com o modelo de peixezebra.

Discussão: Têm sido desenvolvidas poderosas ferramentas genéticas e de microscopia in vivo, que também tornaram o peixe-zebra num modelo valioso em investigação biomédica. A conjugação destes atributos com a optimização de sistemas automatizados de triagem de medicamentos, transformaram o peixe-zebra num top model da investigação em biomedicina, nomeadamente na triagem de compostos químicos com efeitos terapêuticos e em testes de toxicidade. Além disso, com a otimização da tecnologia dos xenografos será possível usar o peixe-zebra na escolha de uma terapia personalizada.

Conclusão: O peixe-zebra é um excelente organismo modelo na pesquisa biomédica, em screens de medicamentos e na terapia clinica. Palavras-chave: Avaliação Pré-Clínica de Medicamentos; Investigação Biomédica; Modelos Animais de Doença; Peixe Zebra.

\section{INTRODUCTION}

The zebrafish (Danio rerio) is a tropical freshwater fish native to the northern Indian subcontinent (Fig.s $1 \mathrm{~A}$ and 1B). The species arose in the Ganges region in eastern India, and is commonly found in slow-moving or stagnant water. ${ }^{1}$ Due to zebrafish large fecundity and fertility rates it has become an important model organism for genetic studies. It started as a great model for vertebrate embryonic development, due to its transparency and optic clearance, to become an excellent model in adult stem cell and regenerative medicine. ${ }^{2}$ Zebrafish embryos, larvae and adults are now commonly used as a model for accessing gene function in several human diseases.

Zebrafish importance as a research vertebrate model system in the field of biomedicine has been strengthened by their amenity for large-scale forward genetic screens, such as those known as the Tübingen and Boston screens. ${ }^{3}$ Gene knockdown can also be achieved transiently and effectively with Morpholino (MO) antisense oligonucleotide technology or in a permanent way with the use of custom zinc finger nucleases (ZFNs), ${ }^{4}$ and transcription activator-like effector nucleases (TALENs). ${ }^{5}$ More recently, another technology based on bacterial clustered, regularly interspaced, short palindromic repeats (CRISPR) and associated (Cas) systems (CRISPR-Cas) was shown to function in vivo to induce targeted genetic modifications in zebrafish embryos in a cheaper and equally efficient way. ${ }^{6}$ These technologies have been used to introduce locus-specific double-stranded breaks in the zebrafish genome, generating many mutant alleles that copy human disease loci. Thus, both forward and reverse genetic tools are available. Additionally, zebrafish allows for excellent quality in vivo and ex vivo imaging, ${ }^{7}$ offering the choice among several powerful techniques such

1. Centro de Estudos de Doenças Crónicas. Faculdade de Ciências Médicas de Lisboa. Lisboa. Portugal.

Recebido: 19 de Julho de 2013 - Aceite: 27 de Julho de 2013 | Copyright @ Ordem dos Médicos 2013 

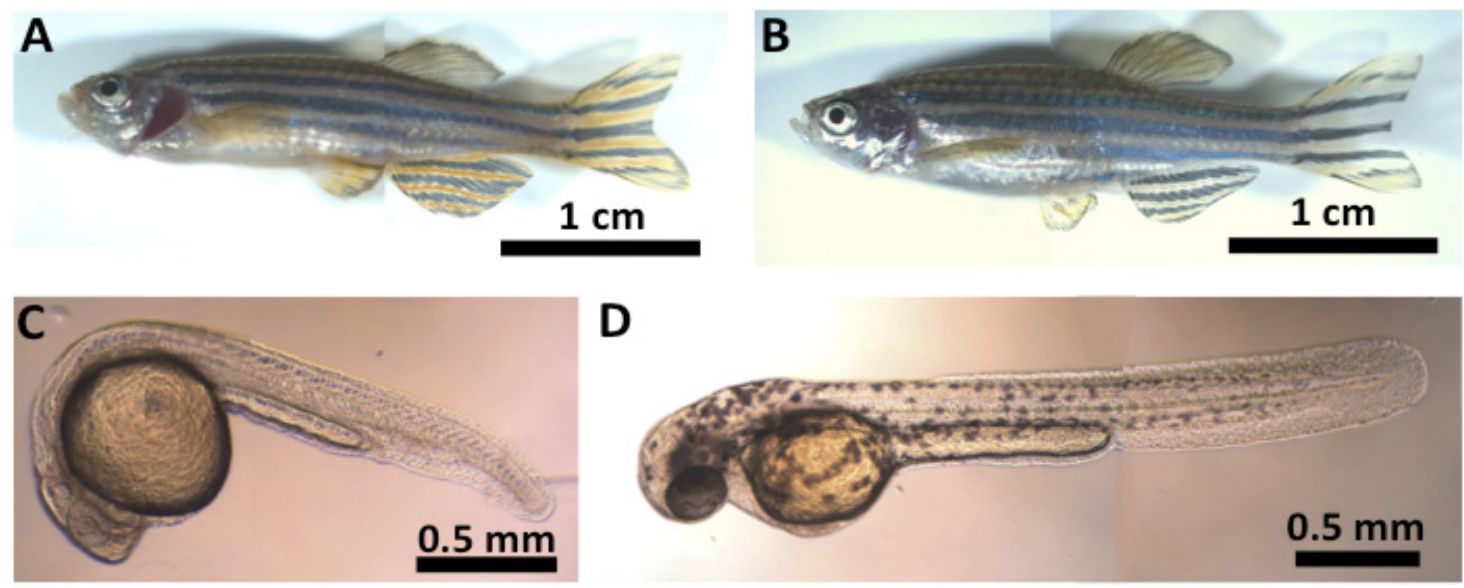

D

\section{E}

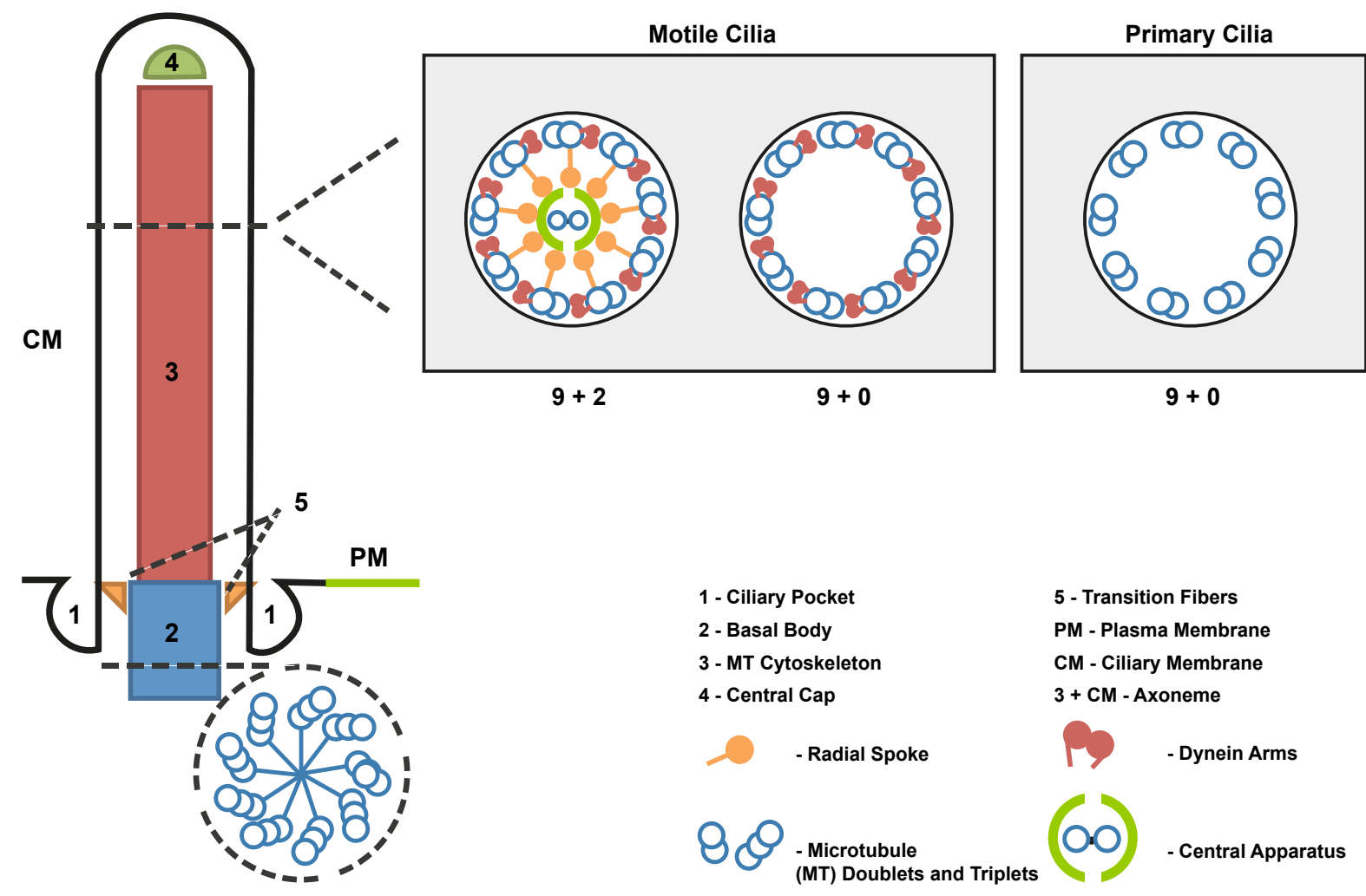

Figure 1 - A) Adult male zebrafish (12 months old). B) Adult female zebrafish (12 months old). C) 24 hpf (hours post fertilization) zebrafish embryo. D) 48 hpf zebrafish larvae. E) Schematic ciliary structure.

as fluorescent confocal microscopy, or even bright field live video microscopy. Furthermore, the research community is supported by an excellent curated database of genetic, genomic, and developmental information - the Zebrafish Model Organism Database (ZFIN). ${ }^{8}$

As a vertebrate model, zebrafish possess several advantages, such as a fully sequenced genome, a very rapid embryologic development outside of the mother's body (Fig.s 1C and 1D), and a well-characterized behavior of easy observation. Moreover, there are several mutant and transgenic strains available. One example is the casper mutant strain with transparent skin in the adult fish, allowing for detailed visualization of organs and cellular activity, circulation, metastasis, among other phenomena. ${ }^{9}$ Zebrafish has been shown to be similar to mammalian biological models when it comes to toxicity tolerance and circadian rhythms. ${ }^{10}$ Nevertheless, they are capable of regenerating several tissues, like fins, ${ }^{11}$ heart, ${ }^{2}$ photoreceptor cells and retinal neurons, ${ }^{12}$ and even spinal cord..$^{13}$ Furthermore, several studies have been made over the years in development and differentiation of the nervous system in zebrafish, allowing for the mapping of their brain networks ${ }^{14}$ which will facilitate the study of human neurological diseases. Altogether the tools available and the plasticity of this biological model allowed 
for the establishment of zebrafish as a human disease model for cancer, cardiovascular and immune system diseases, and many others.

In this review we will emphasize the role of zebrafish, as a biomedical vertebrate model. We will focus on five main human illnesses, chosen for their high prevalence or their chronicity: cancer, diabetes and lipid-related diseases, cardiovascular disease, neurodegeneration and ciliopathies. We will also report the use of zebrafish in drug screening and the translational work currently being done with zebrafish in Portugal.

\section{Zebrafish as a Human Disease Model 1. Cancer}

Zebrafish was first used in cancer research during the 1960s, when Stanton et al. used it to test the effects of carcinogens. ${ }^{15}$ Zebrafish have a very low rate of spontaneous neoplasia, with only $\sim 10 \%$ of zebrafish developing a tumor over their lifetime. Nevertheless, when exposed to carcinogenic agents such as DENA (diethylnitrosamine), MNNG (N-methyl-N-nitro-N-nitrosoguanidine), and DMBA (7.12 - dimethylbenz(a)anthracene), the fish will develop cancer. ${ }^{15-18}$ Furthermore, zebrafish has proven to be an ideal model to study the malignancy of several tumors by means of tumor transplantation assays. ${ }^{19}$ These were shown to be robust and have the added advantage of the fish high fecundity, providing high numbers of donor and recipient fish. Not only have several types of cancer been studied with this model, such as leukemia, ${ }^{20,21}$ melanoma, endocrine or liver cancer $^{16,19,20}$ but more importantly, by means of the xenotransplantation of human tumor cells into zebrafish embryos (xenografts) it is possible to address tumor cell migration, metastasis, angiogenesis, ${ }^{24-26}$ and also the effects of potential therapeutic targets. ${ }^{19}$ Together with the easily available forward and reverse genetic tools, and the non-invasive in vivo imaging technology, these characteristics have made of zebrafish an ideal vertebrate model to study cancer. ${ }^{27}$

Notwithstanding the evolutionary gap between fish and human, there is a manifest histological similarity between tumors formed in fish and those in human, with many important genes and pathways involved in cancer being maintained in both species (Table 1). ${ }^{27}$ One such example is that of the p53 tumor-suppressor protein. This transcription factor is essential in regulating cell death, proliferation, and maintenance of genomic stability, and its mutation has been associated with more than $50 \%$ of all human tumors. ${ }^{28}$ In 2005, a forwards genetic study generated and identified three $p 53$ missense mutations in zebrafish, of which two had been previously reported in human tumors. ${ }^{29}$ These mutant fish developed tumors at an early age. Despite differences in p53 transcription regulation, ${ }^{30}$ the zebrafish model for this pathway showed conservation of its main functions, like the role of p53 in DNA damage-induced apoptosis. Additionally, the development of antibodies for zebrafish p53 protein has contributed for the value of this model in the study of p53 in the context of cancer. ${ }^{27,30}$

Recently, zebrafish has become an interesting model for the study of melanoma progression. It has been well established that mutations that activate the RAS/RAF/MEK/ ERK signaling cascade, notably mutations in the BRAF and NRAS genes, are very common in this type of tumor. ${ }^{32}$ To further determine the role of these genes in the progression of the disease, several transgenic fish lines were generated. While the BRAF mutant fish developed large agglomerates of proliferating melanocytes, which histologically resembled human nevi, the NRAS mutant fish displayed severe defects in pigment patterning but did not quickly developed melanoma. Interestingly, when both transgenic fish lines were crossed with p53 mutant lines, the melanoma phenotype progressed significantly faster, highlighting the importance of p53 function in melanoma tumor suppression. ${ }^{33,34} \mathrm{~A}$ third transgenic fish line was developed, expressing the oncogenic human HRAS gene in the melanocytic cell line. Research performed with these fishes suggested a role for epigenetic regulation in this melanoma model. ${ }^{35}$ Overall, these results show that zebrafish melanomas resemble human disease morphologically, genetically and epigenetically, demonstrating zebrafish suitability as a melanoma model. ${ }^{27}$

Another type of cancer that found in zebrafish an adequate model was the acute lymphoblastic leukemia (ALL), a disease with relatively homogeneous morphology and immunophenotype, but with great heterogeneity at the genetic level, which can lead to distinct responses to therapy. ${ }^{27}$ One of the main causes of ALL is the TEL-AML1 fusion, associated with B-lymphocytes. Transgenic fish were generated with this mutation in all cell lineages, and developed lymphoblastic leukemia, which phenocopied the childhood CD10+ pre-B ALL. ${ }^{36}$ T-cell ALL modeling in zebrafish was achieved by creating a transgenic line for the oncogene Myc. ${ }^{37}$ Other mechanisms responsible for ALL have also been addressed with zebrafish, such as Notch1-induced T-ALL. ${ }^{38}$

The oncogene Kras in pancreatic cancer and in rhabdomyosarcomas was also studied with zebrafish. Several transgenic lines for pancreatic cancer have been created allowing findings on cancer initiation and progression, as well as on defining the cell of origin for invasive pancreatic ductal adenocarcinomas, acinar cell carcinomas and adenocarcinomas with mixed acinar and ductal features. This same Kras transgenic line also developed very aggressive muscle tumors that resembled the human embryonic rhabdomyosarcoma, and was used for gene-expression analysis of both Kras-dependent types of cancer. ${ }^{27}$ Other gene-based models have been created by target-selected mutagenesis strategies. These include the tumor-suppressor genes adenomatous polyposis coli (APC) and phosphatase and tensin homolog on chromosome 10 (PTEN), and the MYCNdriven pancreatic neuroendocrine carcinoma. Results from all these studies have enhanced our understanding of the biology behind cancer. Such studies have the potential to lead to advances in treatment of the pathology. These facts together with the power of forward and reverse genetic screens, and xenotransplantations of cancer cells (e.g. ZFCANCER - FP7 project), have further cemented zebrafish as a vertebrate model for cancer. ${ }^{27}$ 
Table 1 - Zebrafish models of human diseases.

\begin{tabular}{|c|c|c|c|c|}
\hline Zebrafish Mutant & $\begin{array}{c}\text { Gene } \\
\text { Affected }\end{array}$ & Phenotype & Human Disease & References \\
\hline $\begin{array}{l}\text { tp53 }{ }^{\mathrm{N} 168 \mathrm{~K}} \text { null } \\
\text { mutation }\end{array}$ & tp53 & $\begin{array}{l}\text { Malignant peripheral nerve sheath tumors; failure to } \\
\text { activate apoptosis }\end{array}$ & Cancer & $(29)$ \\
\hline $\begin{array}{l}\text { tp53 } 3^{\text {м214K }} \text { null } \\
\text { mutation }\end{array}$ & tp53 & $\begin{array}{l}\text { Malignant peripheral nerve sheath tumors; failure to } \\
\text { activate apoptosis }\end{array}$ & Cancer & $(29)$ \\
\hline BRAF mutant & braf & $\begin{array}{l}\text { Large lesions of proliferating melanocytes, which } \\
\text { histologically resembled human nevi }\end{array}$ & Melanoma & (33) \\
\hline NRAS mutant & nras & Severe defects in pigment patterning & Melanoma & (34) \\
\hline HRAS mutant & hras & Melanoma & Melanoma & $(35)$ \\
\hline $\begin{array}{l}\text { Transgenic } \\
\text { expression }\end{array}$ & $\begin{array}{l}\text { tel/aml1 } \\
\text { fusion }\end{array}$ & Acute lymphoblastic leukemia & $\begin{array}{l}\text { Childhood CD } 10+\text { precursor } \\
\text { B-lymphocyte acute } \\
\text { lymphoblastic leukemia }\end{array}$ & $(36)$ \\
\hline $\begin{array}{l}\text { Transgenic } \\
\text { expression }\end{array}$ & $c-m y c$ & Acute lymphoblastic leukemia & $\begin{array}{l}\text { T-cell acute lymphoblastic } \\
\text { leukemia }\end{array}$ & $(37)$ \\
\hline $\begin{array}{l}\text { Transgenic } \\
\text { expression }\end{array}$ & kras & Tumors in pancreas and muscle & $\begin{array}{l}\text { Pancreatic cancer and } \\
\text { rhabdomyosarcomas }\end{array}$ & (27) \\
\hline apc null mutation & $a p c$ & Tumors in liver and intestine & Colon cancer & (27) \\
\hline MO & pten & Ocular tumors & Cancer & $(27)$ \\
\hline $\begin{array}{l}\text { Transgenic } \\
\text { expression }\end{array}$ & mycn & $\beta$-islet cell neuroendocrine carcinoma & $\begin{array}{l}\text { MYCN-driven pancreatic } \\
\text { neuroendocrine carcinoma }\end{array}$ & $(27)$ \\
\hline heart-strings (hst) & $t b \times 5$ & $\begin{array}{l}\text { Abnormalities in cardiac differentiation and fin } \\
\text { development }\end{array}$ & $\begin{array}{l}\text { Holt-Oram syndrome with } \\
\text { cardiac septation defects and } \\
\text { limb abnormalities }\end{array}$ & $(52)$ \\
\hline slipjig (sli) & foxn4 & $\begin{array}{l}\text { Structural atrioventricular canal malformation } \\
\text { accompanied by atrioventricular conduction defects }\end{array}$ & $\begin{array}{l}\text { Atrioventricular canal defects in } \\
\text { humans }\end{array}$ & $(52)$ \\
\hline gridlock (grl) & hey2 & $\begin{array}{l}\text { Impaired blood flow in the tail owing to arterial } \\
\text { blockade in the anterior trunk, hyperplastic hearts }\end{array}$ & Congenital aortic coarctation & $(52)$ \\
\hline island beat (isl) & $C-L T C C$ & $\begin{array}{l}\text { Reduced number of ventricular cardiac myocytes } \\
\text { and arrhythmia }\end{array}$ & & $(52)$ \\
\hline liebeskummer (lik) & ruvb/2 & Cardiac hyperplasia & & $(52)$ \\
\hline $\begin{array}{l}\text { heart of glass (heg), } \\
\text { santa (san) and } \\
\text { valentine (val) }\end{array}$ & $\begin{array}{l}\text { heg, krit1 } \\
\text { and } c c m 2\end{array}$ & $\begin{array}{l}\text { Formation of hypocontractile, monolayered, giant } \\
\text { cardiac ventricles }\end{array}$ & & $(52)$ \\
\hline dead beat (ded) & PLCG1 & Loss of cardiac contractility between $48-60 \mathrm{hpf}$ & DMC & $(52)$ \\
\hline main squeeze (msq) & ILK & Loss of cardiac contractility between $60-72 \mathrm{hpf}$ & DMC & $(52)$ \\
\hline pickwick (pik), & titin & Zebrafish do not form cardiac sarcomeres & DMC & (52) \\
\hline tell tale heart (tel) & $m / c 2$ & Zebrafish do not form cardiac sarcomeres & $\mathrm{HCM}$ & $(52)$ \\
\hline silent heart (sil) & TNNT2 & $\begin{array}{l}\text { Ventricular acontractility owing to impaired } \\
\text { myofibrillogenesis }\end{array}$ & $\mathrm{HCM}$ & $(52)$ \\
\hline erg & $\begin{array}{l}\text { kcnh2 (loss } \\
\text { of function) }\end{array}$ & $\begin{array}{l}\text { Complete atrioventricular block and ventricular } \\
\text { asystole }\end{array}$ & Long QT syndrome & $(52)$ \\
\hline reggae (reg) & $\begin{array}{l}\text { kcnh2 (gain } \\
\text { of function) }\end{array}$ & $\begin{array}{l}\text { Accelerated repolarization and paroxysmal atrial } \\
\text { fibrillation }\end{array}$ & Short QT syndrome & $(52)$ \\
\hline slow mo (smo) & hen & Bradycardia & Bradycardia & $(52)$ \\
\hline tremblor (tre) & NCX & Atrial fibrillation & Arrhythmia & $(52)$ \\
\hline MO & parkin & $\begin{array}{l}20 \% \text { loss of DA neurons in the vDC with increased } \\
\text { susceptibility to PD-inducing neurotoxins }\end{array}$ & $\begin{array}{l}\text { Autosomal-recessive early- } \\
\text { onset PD }\end{array}$ & $(55)$ \\
\hline MO & pink1 & $\begin{array}{l}40 \% \text { reduction in the number of DA neurons in the } \\
\text { vDC, impaired response to touch stimuli, reduced } \\
\text { swimming behavior, and mitochondrial defects }\end{array}$ & $\begin{array}{l}\text { Autosomal-recessive early- } \\
\text { onset PD }\end{array}$ & $(55)$ \\
\hline MO & $d j-1$ & DA neurons more sensitive to oxidative stress & $\begin{array}{l}\text { Autosomal-recessive early- } \\
\text { onset PD }\end{array}$ & $(55)$ \\
\hline MO & irrk2 & $\begin{array}{l}\text { Loss of DA neurons in the vDC and locomotor } \\
\text { defects }\end{array}$ & $\begin{array}{l}\text { Autosomal-dominant early- } \\
\text { onset PD }\end{array}$ & $(55)$ \\
\hline Transient OE & $\begin{array}{l}\text { Mhtt (Q102- } \\
\quad h t t)\end{array}$ & $\begin{array}{l}\text { Accumulation of Htt:GFP aggregates throughout } \\
\text { the body of embryos at } 24 \mathrm{hpf} \text {, with soluble forms of } \\
\mathrm{mHtt} \text { proving neurotoxic }\end{array}$ & HD & (55) \\
\hline MO & appa, appb & $\begin{array}{l}\text { Reduced body length and defective convergent- } \\
\text { extension movements during gastrulation. Defects } \\
\text { are rescued by wild-type human APP mRNA, but not } \\
\text { by the Swedish mutant APP }\end{array}$ & Familial AD & (55) \\
\hline $\begin{array}{l}\text { Transgenic } \\
\text { expression }\end{array}$ & $\begin{array}{l}\text { mutant } \\
\text { human } \\
\text { MAPT }\end{array}$ & $\begin{array}{l}\text { tau hyperphosphorylation, tangle formation, } \\
\text { neurodegeneration in the spinal cord, and behavioral } \\
\text { deficits in escape response }\end{array}$ & $A D$ & (55) \\
\hline
\end{tabular}

MO - Morpholino oligonucleotide, OE - over expression, hpf - hours post fertilization. 


\section{Diabetes and Lipid-related Diseases}

Due to the amenability of zebrafish for developmental studies, there is an accurate description of pancreas development and morphogenesis for this species. Studies performed in zebrafish have specifically led to the understanding of extrinsic signaling molecules, like retinoic acid, Shh and FGF, in influencing intrinsic transcriptional programs. ${ }^{39,40}$ These efforts have made zebrafish an alternative model to study not only the onset of diabetes but also its treatment. Zebrafish become hyperglycemic if exposed to high glucose and develop retinopathies with prolonged high blood sugar levels. Additionally, zebrafish also react satisfactorily to anti-diabetic drugs. ${ }^{41,42}$

The suitability of the zebrafish as a model for lipid-related diseases lies with the fact that they possess remarkable similarities with mammals in their lipid absorption, processing and metabolism, together with the possibility of applying imaging methods with subcellular resolution to a whole organism, thanks to the availability of fluorescent lipid dyes. ${ }^{43,44}$ Zebrafish has been shown to be an adequate atherosclerosis model, allowing for the analysis of the lesion development, by imaging lipid deposition and cellular changes in the vascular wall, and by visualization of macrophage lipid deposition in vivo. ${ }^{45}$ Obesity has also been addressed with zebrafish, since their energy homeostasis resembles that of mammals, including a melanocortin system that responds to leptin, ${ }^{46}$ and similar response to compounds known to modulate the fat content in mammals. ${ }^{47}$ Lastly, the metabolism of cholesterol in zebrafish shares many of its features with that of mammals. Both share key transcriptional regulators - SREBP (sterol-regulatory-element-binding protein) and LXR (liver $X$ receptor) systems, and mutant fish for genes involved show similar phenotypes to the equivalent human pathologies. ${ }^{48,49}$

\section{Cardiovascular Diseases}

In recent years, the development of the cardiovascular system in zebrafish has been thoroughly studied and characterized, greatly accelerating our knowledge of cardiac development, angiogenesis and vasculogenesis. The amenability of this model for cardiovascular studies lies with its external embryological development, its optical clarity as an embryo, closed cardiovascular system and similar cardiac cycle. All these features allow the sequential observation of the developing heart and blood vessels without invasive techniques in both wild type and mutant embryos. ${ }^{50-52}$ Since zebrafish regenerate their hearts, researchers have investigated the origins of defects in heart size, shape, and function, and most importantly have looked for the cellular sources or stem cells involved in the regeneration of the cardiac muscle. ${ }^{52-54}$ Several human cardiovascular diseases have also been addressed with zebrafish disease models, like the Holt-Oram syndrome, congenital defects in the atrioventricular canal and aortic coarctation, dilated cardiomyopathy (DCM) and hypertrophic cardiomyopathy (HCM), long and short QT syndromes, and other arrhythmias (Table 1)..$^{52}$

\section{Neurodegeneration}

Zebrafish brain shows many organizational similarities and homologies with the human brain, specifically the presence of a fore, mid and hindbrain, including a diencephalon, telencephalon and cerebellum. Zebrafish also display complex behaviors such as memory, conditioned responses, and schooling. ${ }^{55}$

Many neurodegenerative diseases have been tackled with this model. Several homologues of Parkinson's disease (PD) associated genes have been found in zebrafish, including parkin, pink1, dj-1, and Irrk2, that have shown conserved functions in the development and survival of dopaminergic (DA) neurons (Table 1). Furthermore, studies in the sporadic form of PD have also been performed in zebrafish, by means of the neurotoxin MPTP (1-methyl4-phenyl-1,2,3,6-tetrapyridine). This drug induced a transient decrease in dopamine levels, behavioral defects, and a significant reduction of DA neurons in the vDC (ventral diencephalon). ${ }^{55}$

Huntington's disease (HD) has been studied in zebrafish with antisense Morpholino (MO) technology. These have indicated a role in cellular iron utilization for $\mathrm{Htt}$, with blood hypochromia, and loss of sensory neurons and telencephalic tissue as the main phenotypes. Overexpression studies of mutant $\mathrm{Htt}$ proteins (Q102 $\mathrm{mHtt}$ ) in zebrafish have also allowed for the photocopying of HD symptoms and drug screen studies (Table 1). ${ }^{55}$

Zebrafish has shown to be a good model for research in Alzheimer's disease (AD), allowing insights into the roles of the APP and MAPT (Tau) proteins in this disease (Table 1). ${ }^{55}$

\section{Ciliopathies}

Cilia or flagella are ubiquitous organelles with a highly conserved structure, which can be found in a large variety of organisms from single cell eukaryotes to the majority of mammalian cell types. Cilia and flagella are constituted by an axoneme made by a microtubule (MT) cytoskeleton enveloped in a ciliary membrane. Cilia can be divided in two main types, motile and immotile, both having an axoneme constituted by nine MT doublets. Whereas immotile cilia, also known as primary cilia, have no further structures, motile cilia are equipped with extra structures, namely outer and inner dynein arms (ODAs and IDAs, respectively) that generate the necessary force for motility. Additionally, most motile cilia also possess a central apparatus made of two MTs, several radial spokes and central pair projections that regulate and propagate the motor activity through the cilium (Figure 1 - E). ${ }^{56,57}$

Motile cilia are involved in cell motility, as is the case of several ciliated eukaryotes like Trypanosoma brucei or Paramecium (with one flagellum and hundreds of small cilia, respectively). In multicellular organisms, motile cilia are involved in propelling sperm and in moving extracellular fluids, such as mucus in respiratory airways ${ }^{56,58}$ or the cerebrospinal fluid ${ }^{56,59}$ A special type of motile cilia, with a 9+0 axoneme, present in the embryonic node was shown to 
Table 2 - Ciliopathies, major clinical features and genes involved.

\begin{tabular}{|c|c|c|}
\hline Ciliopathy & Major clinical features & Genes involved \\
\hline BBS & $\begin{array}{l}\text { Retinitis pigmentosa, Renal cystic } \\
\text { disease, Polydactyly, Situs inversus/ } \\
\text { Isomerism, Mental retardation, Hypoplasia } \\
\text { of corpus callosum, Dandy-Walker } \\
\text { malformation, Hepatic disease }\end{array}$ & $\begin{array}{l}\text { BBS1, BBS2, BBS4, BBS5, BBS7, BBS9/PTHB1, BBS10/C12ORF58/FLJ23560, } \\
\text { TRIM32/BBS11, BBS12, MKKS/BBS6, ARL6/BBS3/RP55, TTC8/BBS8/RP51, } \\
\text { WDPCP/C2ORF86/BBS15/FRITZ, MKS1/BBS13, CEP290/NPHP6/BBS14/JBTS5, } \\
\text { TMEM67/MKS3/JBTS6/NPHP11, KIF7/JBTS12 }\end{array}$ \\
\hline MKS & $\begin{array}{l}\text { Retinitis pigmentosa, Renal cystic } \\
\text { disease, Polydactyly, Situs inversus/ } \\
\text { Isomerism, Mental retardation, Hypoplasia } \\
\text { of corpus callosum, Dandy-Walker } \\
\text { malformation, Hepatic disease, Posterior } \\
\text { encephalocele }\end{array}$ & $\begin{array}{l}\text { WDPCP/C2ORF86/BBS15/FRITZ, MKS1/BBS13, CEP290/NPHP6/BBS14/JBTS5, } \\
\text { TMEM67/MKS3/JBTS6/NPHP11, RPGRIP1L/JBTS7/NPHP8/MKS5, CC2D2A/JBTS9/ } \\
\text { MKS6, TMEM216/MKS2/JBTS2, NPHP3/MKS7, TCTN2/MKS8, B9D1/MKS9, B9D2/ } \\
\text { MKS10 }\end{array}$ \\
\hline JBTS & $\begin{array}{l}\text { Retinitis pigmentosa, Renal cystic } \\
\text { disease, Polydactyly, Situs inversus/ } \\
\text { Isomerism, Mental retardation, Hypoplasia } \\
\text { of corpus callosum, Dandy-Walker } \\
\text { malformation, Posterior encephalocele, } \\
\text { Hepatic disease }\end{array}$ & $\begin{array}{l}\text { CEP290/NPHP6/BBS14/JBTS5, TMEM67/MKS3/JBTS6/NPHP11, RPGRIP1L/JBTS7/ } \\
\text { NPHP8/MKS5, CC2D2A/JBTS9/MKS6, TMEM216/MKS2/JBTS2, NPHP1/JBTS4/ } \\
\text { SLSN1, TTC21B/JBTS11/NPHP12/ATD4, ARL13B/JBTS8 (ARL2L1), INPP5E/JBTS1, } \\
\text { AHI1/Jouberin/JBTS3, KIF7/JBTS12, TCTN1/JBTS13, OFD1/CXORF5/JBTS10 }\end{array}$ \\
\hline NPHP & $\begin{array}{l}\text { Polyuria, Polydipsia, Proteinuria } \\
\text { End-stage kidney disease, Retinitis } \\
\text { pigmentosa, Hepatic disease, Mental } \\
\text { retardation, }\end{array}$ & $\begin{array}{l}\text { CEP290/NPHP6/BBS14/JBTS5, TMEM67/MKS3/JBTS6/NPHP11, RPGRIP1L/JBTS7/ } \\
\text { NPHP8/MKS5, NPHP3/MKS7, NPHP1/JBTS4/SLSN1, TTC21B/JBTS11/NPHP12/ } \\
\text { ATD4, SDCCAG8/SLSN7/NPHP10, NPHP4/SLSN4, GLIS2/NPHP7, WDR19/NPHP13/ } \\
\text { ATD5, NEK8/NPHP9, INVS/NPHP2 }\end{array}$ \\
\hline SLSN & $\begin{array}{l}\text { Retinitis pigmentosa, Renal cystic } \\
\text { disease, Situs inversus/lsomerism, Dandy- } \\
\text { Walker malformation, Hepatic disease }\end{array}$ & $\begin{array}{l}\text { CEP290/NPHP6/BBS14/JBTS5, NPHP1/JBTS4/SLSN1, SDCCAG8/SLSN7/NPHP10, } \\
\text { NPHP4/SLSN4, IQCB1/NPHP5/SLSN5 }\end{array}$ \\
\hline LCA/RP & Severe vision loss or blindness & $\begin{array}{l}\text { ARL6/BBS3/RP55, TTC8/BBS8/RP51, CEP290/NPHP6/BBS14/JBTS5, RPGRIP1L/ } \\
\text { JBTS7/NPHP8/MKS5, IQCB1/NPHP5/SLSN5, RPGR/RP3, LCA5/lebercilin, RP1, RP2, } \\
\text { RPGRIP1, MAK }\end{array}$ \\
\hline MKKS & $\begin{array}{l}\text { Congenital hydrometrocolpos, Respiratory } \\
\text { embarrassment, Urinary, intestinal, } \\
\text { circulatory obstruction, Congenital heart } \\
\text { defect, Polydactyly }\end{array}$ & MKKS/BBS6 \\
\hline JATD & $\begin{array}{l}\text { Skeletal dysplasia, Polydactyly, Renal, } \\
\text { liver, pancreas and retinal abnormalities }\end{array}$ & $\begin{array}{l}\text { TTC21B/JBTS11/NPHP12/ATD4, WDR19/NPHP13/ATD5, ATD1, IFT80/ATD2, } \\
\text { DYNC2H1/ATD3 }\end{array}$ \\
\hline ALMS & $\begin{array}{l}\text { Dilated cardiomyopathy, Cone-rod } \\
\text { dystrophy, Developmental delays, Obesity }\end{array}$ & ALMS1 \\
\hline PKD & Polycystic kidneys & PC1/PKD1, PC2/PKD2 \\
\hline
\end{tabular}

generate a leftward fluid flow (nodal flow) that is involved in left-right body axis determination. ${ }^{56,58,60}$

Up until the late 1990's, the primary cilia were described as an evolutionary 'remnant' with no relevant function. Nevertheless almost all mammalian cell types assemble a primary cilium after exiting the cell cycle. ${ }^{57}$ Only in 2000 was the primary cilium associated with a common human disease, when Pazour et al. showed that Chlamydomonas IFT88 mutants had no flagella and that the mice mutated for the IFT88 orthologue, Polaris, suffered from polycystic kidney disease (PKD). ${ }^{57,61}$ Since then, several diseases have been associated with primary or motile cilia misassembly or malfunction and have collectively been designated as ciliopathies (Table 2). ${ }^{56,57}$

Ciliopathies are characterized by a large diversity of usually overlapping symptoms (Table 2), with mutations in different genes causing the same disease, and mutations in the same gene causing different pathologies. ${ }^{62}$ Several explanations have been suggested for this phenomenon, such as the effect of mutations on protein function, the pattern of expression of the mutated gene, and the mutational load across different ciliary genes. ${ }^{63}$ These characteristics make the study of ciliopathies more complex. In addition to some ciliated cell lines available for primary cilia, several model organisms have been used during the last decade in the study of ciliopathies. Perhaps one of the best animal models for these diseases is the zebrafish for combining the presence of all types of cilia and for being a vertebrate.

Zebrafish embryos contain several ciliated organs, with both motile and primary cilia. Zebrafish has become an important model system in the study of renal diseases, such as PKD and acute kidney injury (AKI), and in the search of new therapeutics due to the structural and functional simplicity of its embryonic kidney. ${ }^{56,64}$ In our group, we take advantage of zebrafish embryonic transparency and use a ciliated organ - Kupffer's Vesicle - to study cilia length regulation and ciliary motility. How does beat frequency and length modulate fluid flow is one of our main questions, with the ultimate objective of understanding fluid and ciliary dynamics in respiratory diseases, polycystic kidney disease and situs inversus. 


\section{Zebrafish and Drug Screening}

Over all zebrafish's characteristics make them ideal for fast, reliable and low-cost drug screenings during pre-regulatory phases of drug development or repositioning and they can now be used in high-throughput screening (HTS) of drug libraries. ${ }^{65-67}$ This screening procedure involves obtaining zebrafish embryos or larvae, at the same development stage, loading them into multiwell plates, dosing the plates with chemical compounds, and then checking for changes elicited by the drugs at different concentrations, with the aim of improving the zebrafish phenotype that mimics a specific human disease. ${ }^{65,67,68}$ True HTS use robotics and automated fluid handling systems. These technologies have been adapted in the vertebrate automated screening technology (VAST), which loads live larvae from a reservoir and positions it into a capillary-based imaging chamber that can be rotated for an optimal field-of-view. After imaging, further manipulations can be performed, and then the larvae are automatically returned to their original container. ${ }^{67,68}$ This basic model of HTS, with or without the automatization provided by robotics, has allowed for many types of studies, such as new or repositioning drug screens for a variety of diseases like cardiovascular, polycystic kidneys, cancer ${ }^{69,70}$ and obesity; screening for regeneration, psychotropic, antimicrobial and immunosuppressant drugs; sensory organ and behavioral screens; screening of bioactive natural products; and toxicology studies. ${ }^{67,68,71-74}$ Recently, Leonard Zon's team has identified two new drugs that are now in early clinical trials in cancer patients. They have also discovered a new use for FT1050, a chemical variant of

Table 3 - Main Portuguese fundamental and biomedical research groups working with zebrafish model.

\begin{tabular}{|c|c|c|c|c|}
\hline Group & $\begin{array}{c}\text { Principal } \\
\text { Investigator }\end{array}$ & Main Interests & Affiliation & Location \\
\hline $\begin{array}{l}\text { EDGE Molecular } \\
\text { Biology }\end{array}$ & Leonor Cancela & $\begin{array}{l}\text { Skeletogenesis and vertebrate skeletal } \\
\text { development }\end{array}$ & CCMAR, UALG & Algarve \\
\hline $\begin{array}{l}\text { Tissue Morphogenesis } \\
\text { and Repair }\end{array}$ & António Jacinto & Wound healing and tissue regeneration & CEDOC, FCM/UNL & Lisbon \\
\hline $\begin{array}{l}\text { Cilia Regulation } \\
\text { and Disease }\end{array}$ & Susana Lopes & Ciliogenesis, cilia length and motility regulation & CEDOC, FCM/UNL & Lisbon \\
\hline $\begin{array}{l}\text { Stress } \\
\text { Biology }\end{array}$ & Manuel Santos & $\begin{array}{l}\text { Biology of small RNAs, the genetic code, } \\
\text { and the origin of life }\end{array}$ & CESAM, UA & Aveiro \\
\hline $\begin{array}{l}\text { Intelligent } \\
\text { Systems }\end{array}$ & Adam Kampff & $\begin{array}{l}\text { Structural modulation of the world by the } \\
\text { nervous system, learning, coding } \\
\text { information in a nervous network and behavior }\end{array}$ & $\mathrm{CCU}, \mathrm{CF}$ & Lisbon \\
\hline $\begin{array}{l}\text { Vision } \\
\text { to Action }\end{array}$ & Michael Orger & Integration of visual information and behavior & $\mathrm{CCU}, \mathrm{CF}$ & Lisbon \\
\hline $\begin{array}{l}\text { Fish Nutrition } \\
\text { and Immunobiology }\end{array}$ & $\begin{array}{l}\text { António Paulo } \\
\text { Carvalho }\end{array}$ & $\begin{array}{l}\text { Effect of toxins at the molecular and } \\
\text { organism levels }\end{array}$ & CIIMAR, FCUP & Porto \\
\hline Redox Biology & Susana Marinho & Role of $\mathrm{H}_{2} \mathrm{O}_{2}$ in tumor progression & CQB, FCUL & Lisbon \\
\hline Pharmacology Lab & Glória Queiroz & $\begin{array}{l}\text { Drug testing targeted to mitochondrial } \\
\text { disorders in neurodegenerative diseases }\end{array}$ & DCM, FFUP & Porto \\
\hline $\begin{array}{l}\text { Vertebrate development } \\
\text { and regeneration }\end{array}$ & José Bessa & Pancreas development and function & IBMC, UP & Porto \\
\hline Ecotox & Lúcia Guilhermino & $\begin{array}{l}\text { Ecological and human health risk } \\
\text { assessment }\end{array}$ & ICBAS/CIIMAR, FCUP & Porto \\
\hline $\begin{array}{l}\text { Telomeres and Genome } \\
\text { Stability }\end{array}$ & $\begin{array}{l}\text { Miguel Godinho } \\
\text { Ferreira }\end{array}$ & The role of telomeres in aging and cancer & IGC, FCG & Lisbon \\
\hline $\begin{array}{l}\text { Integrative Behavioral } \\
\text { Biology }\end{array}$ & Rui Oliveira & $\begin{array}{l}\text { Comparative social cognition } \\
\text { Social modulation of adult neurogenesis }\end{array}$ & IGC, FCG & Lisbon \\
\hline $\begin{array}{l}\text { Embryonic Development } \\
\text { of Vertebrates Unit }\end{array}$ & Leonor Saúde & $\begin{array}{l}\text { Left-Right Asymmetry, Somite Formation, } \\
\text { and Organ / Tissue Regeneration }\end{array}$ & IMM, FMUL & Lisbon \\
\hline $\begin{array}{l}\text { Microvascular Biology } \\
\text { and Inflammation Unit }\end{array}$ & Carlota Saldanha & $\begin{array}{l}\text { Inflammation, Leukocyte-endothelium interaction/ } \\
\text { Microcirculation }\end{array}$ & IMM, FMUL & Lisbon \\
\hline $\begin{array}{l}\text { Cell and Molecular } \\
\text { Neuroscience Unit }\end{array}$ & $\begin{array}{l}\text { Tiago Fleming } \\
\text { Outeiro }\end{array}$ & $\begin{array}{l}\text { Development of novel therapeutic approaches } \\
\text { for neurodegenerative diseases }\end{array}$ & IMM, FMUL & Lisbon \\
\hline Angiogenesis Unit & Susana Constantino & $\begin{array}{l}\text { lonizing radiation enhances angiogenesis. } \\
\text { Role of ionizing radiation in metastasis and spinal } \\
\text { cord repair }\end{array}$ & IMM, FMUL & Lisbon \\
\hline TECHNOZeb & Nuno Afonso & Drug screening with impact in bone formation & Technophage, IMM & Lisbon \\
\hline Laboratory Animal Anesthesia & Luis Antunes & Refinement of anesthesia & UTAD & Vila Real \\
\hline Ecointegrity & Ana Coimbra & $\begin{array}{l}\text { Endocrine disruptors effect in sexual } \\
\text { differentiation and signaling, using ovarian } \\
\text { apoptosis as a readout }\end{array}$ & UTAD & Vila Real \\
\hline
\end{tabular}


prostaglandin E2 (PGE2) usually used to treat stomach ulcers. This drug was found to boost the production of blood stem cells and has just successfully concluded Phase 1 of Clinical trials. ${ }^{75}$

\section{Biomedical Research with Zebrafish model in Portugal}

Several Portuguese groups currently use zebrafish as a model for fundamental and biomedical research. Some of these groups and their research focus are summarized in Table 3. The variety in the fields of research is a good indication of the amenity and eclectic usefulness of the zebrafish as a biologic model. For example, zebrafish exceptional ability to regenerate has allowed researchers like Cancela, Jacinto, Saúde and Constantino (Table 3) to study skeletal biomineralization, wound healing, tissue and organ regeneration, and the role of ionizing radiation in spinal cord repair, respectively. The zebrafish embryo/larval transparency has been useful in studies of development of neurological networks, necessary for understanding learning and memory (Kampff and Orger, Table 3). In addition, zebrafish is by far the most versatile vertebrate model organism for studying cilia biology in vivo. Lopes' group is interested in cilia length and motility regulation to understand ciliopathies, whereas Saúde's group is exploiting the role of cilia in tissue regeneration (Table 3 ).

Cancer is currently being investigated with zebrafish in several Portuguese labs (Marinho, Godinho Ferreira and Constantino, Table 3), namely the role of $\mathrm{H}_{2} \mathrm{O}_{2}$ as a signaling molecule in tumor microenvironment and progression, the role of telomeres in cancer, or the mechanisms of tumoral angiogenesis and metastization under ionizing radiation. Behavior and neurogenesis are being studied by Oliveira's group using as a readout zebrafish's natural behavioral patterns (Table 3). Important work is also being done in the role of small RNAs related with environmental stress, genome translation fidelity, proteotoxic stress and human diseases (Santos, Table 3). Saldanha's group is interested in understanding the mechanisms that govern leukocyte recruitment and cell-cell interaction in inflammation and the role of specific inflammatory mediators, such as $\mathrm{H}_{2} \mathrm{O}_{2}$ and Cxcl-8 in this process (Table 3 ).

Research on neurodegenerative disorders is also being undertaken. Outeiro's group focus in developing novel zebrafish models for Parkinson's or Alzheimer's, and intends to test novel drugs for therapeutic value. In the meanwhile Queiroz's group uses zebrafish to test drugs to target mitochondria-associated disorders (Table 3).

Bessa's group uses zebrafish to research the impact that non-coding mutations have in pancreas development and in recapitulating human disorders. Antunes' group use zebrafish in order to refine anesthesia and Coimbra's team studies the role of endocrine disruptors in sexual differentiation (Table 3).

Furthermore, environmental pollution and the effects of chemicals and radiation at the molecular and organism levels are being studied by Carvalho's group, while the impact of these stressors in human health is being addressed through toxicology assays by Guilhermino's group (Table 3). Lastly, the biotech company Technophage has also taken advantage of zebrafish model with the unit TECHNOZeb, which uses larvae and zebrafish adults to screen drug libraries and identify molecules with application in bone disorders like osteoporosis and cancer (Afonso's group, Table 3).

Taken together, these studies prove zebrafish as a successful model system for studying a comprehensive spectrum of diseases that affect millions of humans, and point to a very auspicious future of inexpensive and rapid drug discovery based on the zebrafish model.

\section{CONFLICT OF INTERESTS}

None stated.

\section{FUNDING SOURCE}

PTDC/SAU-OBD/103981/2008 and SFRH/BPD/77258 /2011

10. Jones R. Let sleeping zebrafish lie: a new model for sleep studies. PLoS Biol. 2007;5:e281.

11. Stewart S, Tsun Z-Y, Izpisua Belmonte JC. A histone demethylase is necessary for regeneration in zebrafish. Proc Natl Acad Sci U.S.A. 2009;106:19889-94.

12. Bernardos RL, Barthel LK, Meyers JR, Raymond PA. Late-stage neuronal progenitors in the retina are radial Müller glia that function as retinal stem cells. J Neurosci. 2007;27:7028-40.

13. Goldshmit Y, Sztal TE, Jusuf PR, Hall TE, Nguyen-Chi M, Currie PD. Fgf-dependent glial cell bridges facilitate spinal cord regeneration in zebrafish. J Neurosci. 2012;32:7477-92.

14. Hughes V. Mapping brain networks: Fish-bowl neuroscience. Nature 2013;493:466-8.

15. Stanton MF. Diethylnitrosamine-induced hepatic degeneration and neoplasia in the aquarium fish, brachydanio rerio. J Natl Cancer Inst. 1965;34:117-30.

16. Spitsbergen JM, Tsai H-W, Reddy A, Miller T, Arbogast D, Hendricks JD, et al. Neoplasia in Zebrafish (Danio rerio) Treated with 7,12-Diniethylbenz[a]anthracene by two exposure routes at different developmental stages. Toxicol Pathol. 2000;28:705-15.

17. Spitsbergen JM, Tsai HW, Reddy A, Miller T, Arbogast D, Hendricks JD, et al. Neoplasia in Zebrafish (Danio rerio) Treated with N-methyl-N'nitro- 
$\mathrm{N}$-nitrosoguanidine by three exposure routes at different developmental stages. Toxicol Pathol. 2000;28:716-25.

18. Bourque $\mathrm{C}$, Houvras $\mathrm{Y}$. Hooked on zebrafish: insights into development and cancer of endocrine tissues. Endocr Relat Cancer. 2011;18:R14964.

19. Taylor AM, Zon LI. Zebrafish tumor assays: the state of transplantation. Zebrafish. 2009;6:339-46.

20. Jing L, Zon LI. Zebrafish as a model for normal and malignant hematopoiesis. Dis Model Mech. 2011;4:433-8.

21. Teittinen KJ, Grönroos T, Parikka M, Rämet M, Lohi O. The zebrafish as a tool in leukemia research. Leuk Res. 2012;36:1082-8.

22. Chu J, Sadler KC. New school in liver development: lessons from zebrafish. Hepatology. 2009;50:1656-63.

23. Lu JW, Hsia Y, Tu H-C, Hsiao Y-C, Yang W-Y, Wang H-D, et al. Liver development and cancer formation in zebrafish. Birth Defects Res C Embryo Today. 2011;93:157-72.

24. Tobia C, De Sena G, Presta M. Zebrafish embryo, a tool to study tumor angiogenesis. Int J Dev Biol. 2011;55:505-9.

25. Moshal KS, Ferri-Lagneau KF, Leung T. Zebrafish model: worth considering in defining tumor angiogenesis. Trends Cardiovasc Med. 2010;20:114-9.

26. Jensen LD, Rouhi P, Cao Z, Länne T, Wahlberg E, Cao Y. Zebrafish models to study hypoxia-induced pathological angiogenesis in malignant and nonmalignant diseases. Birth Defects Res C Embryo Today. 2011;93:182-93.

27. Liu S, Leach SD. Zebrafish models for cancer. Annu Rev Pathol. 2011;6:71-93.

28. Zilfou JT, Lowe SW. Tumor suppressive functions of p53. Cold Spring Harb Perspect Biol. 2009;1:a001883

29. Berghmans S, Murphey RD, Wienholds E, Neuberg D, Kutok JL, Fletcher CD, et al. tp53 mutant zebrafish develop malignant peripheral nerve sheath tumors. Proc Natl Acad Sci U.S.A. 2005;102:407-12.

30. Lee K-C, Goh WL, Xu M, Kua N, Lunny D, Wong JS, et al. Detection of the p53 response in zebrafish embryos using new monoclonal antibodies. Oncogene. 2008;27:629-40.

31. Langheinrich U, Hennen E, Stott G, Vacun G. Zebrafish as a model organism for the identification and characterization of drugs and genes affecting p53 signaling. Curr Biol. 2002;12:2023-8.

32. Ghosh P, Chin L. Genetics and genomics of melanoma. Expert Rev Dermatol. 2009;4:131

33. Patton EE, Widlund HR, Kutok JL, Kopani KR, Amatruda JF, Murphey $\mathrm{RD}$, et al. BRAF mutations are sufficient to promote nevi formation and cooperate with p53 in the genesis of melanoma. Curr Biol. 2005;15:249_ 54.

34. Dovey M, White RM, Zon LI. Oncogenic NRAS cooperates with p53 loss to generate melanoma in zebrafish. Zebrafish. 2009;6:397-404.

35. Anelli V, Santoriello C, Distel M, Köster RW, Ciccarelli FD, Mione M. Global repression of cancer gene expression in a zebrafish model of melanoma is linked to epigenetic regulation. Zebrafish. 2009;6:417-24.

36. Sabaawy HE, Azuma M, Embree LJ, Tsai H-J, Starost MF, Hickstein DD. TEL-AML1 transgenic zebrafish model of precursor B cell acute lymphoblastic leukemia. Proc Natl Acad Sci U.S.A. 2006;103:15166-71.

37. Langenau DM, Traver D, Ferrando AA, Kutok JL, Aster JC, Kanki JP et al. Myc-induced T cell leukemia in transgenic zebrafish. Science. 2003;299:887-90

38. Chen J, Jette C, Kanki JP, Aster JC, Look AT, Griffin JD. NOTCH1-induced T-cell leukemia in transgenic zebrafish. Leukemia. 2007;21:46271.

39. Tiso N, Moro E, Argenton F. Zebrafish pancreas development. Mol Cell Endocrinol. 2009;312:24-30.

40. Kinkel MD, Prince VE. On the diabetic menu: zebrafish as a model for pancreas development and function. BioEssays. 2009;31:139-52.

41. Gleeson M, Connaughton V, Arneson LS. Induction of hyperglycaemia in zebrafish (Danio rerio) leads to morphological changes in the retina. Acta Diabetol. 2007;44:157-63.

42. Elo B, Villano CM, Govorko D, White LA. Larval zebrafish as a model for glucose metabolism: expression of phosphoenolpyruvate carboxykinase as a marker for exposure to anti-diabetic compounds. J Mol Endocrinol. 2007;38:433-40.

43. Hölttä-Vuori M, Salo VT V, Nyberg L, Brackmann C, Enejder A, Panula $P$, et al. Zebrafish: gaining popularity in lipid research. Biochem J. 2010;429:235-42.

44. Anderson JL, Carten JD, Farber SA. Zebrafish lipid metabolism: from mediating early patterning to the metabolism of dietary fat and cholesterol. Methods Cell Biol. 2011;101:111-41.

45. Stoletov K, Fang L, Choi S-H, Hartvigsen K, Hansen LF, Hall C, et al.
Vascular lipid accumulation, lipoprotein oxidation, and macrophage lipid uptake in hypercholesterolemic zebrafish. Circ Res. 2009;104:952-60.

46. Song Y, Cone RD. Creation of a genetic model of obesity in a teleost. FASEB J. 2007;21:2042-9.

47. Jones KS, Alimov AP, Rilo HL, Jandacek RJ, Woollett LA, Penberthy WT. A high throughput live transparent animal bioassay to identify nontoxic small molecules or genes that regulate vertebrate fat metabolism for obesity drug development. Nutr Metab. 2008;5:23

48. Archer A, Lauter G, Hauptmann G, Mode A, Gustafsson J-A. Transcriptional activity and developmental expression of liver $X$ receptor (Ixr) in zebrafish. Dev Dyn. 2008;237:1090-8

49. Schlombs K, Wagner T, Scheel J. Site-1 protease is required for cartilage development in zebrafish. Proc Nat Acad Sci USA. 2003;100:14024-9.

50. Holden BJ, Bratt DG, Chico TJ. Molecular control of vascular development in the zebrafish. Birth Defects Res C Embryo Today. 2011;93:134 40.

51. Sabeh MK, Kekhia H, Macrae CA. Optical mapping in the developing zebrafish heart. Pediatric Cardiol. 2012;33:916-22.

52. Dahme T, Katus HA, Rottbauer W. Fishing for the genetic basis of cardiovascular disease. Dis Model Mech. 2009;2:18-22.

53. Liu J, Stainier DY. Zebrafish in the study of early cardiac development. Circ Res. 2012;110:870-4.

54. Kikuchi K, Poss KD. Cardiac regenerative capacity and mechanisms. Annu Rev Cell Dev Biol. 2012;28:719-41.

55. Xi Y, Noble S, Ekker M. Modeling neurodegeneration in zebrafish. Cur Neurol Neurosc Reports. 2011;11:274-82.

56. Vincensini L, Blisnick T, Bastin P. 1001 model organisms to study cilia and flagella. Biol Cell. 2011;103:109-30.

57. Satir P, Christensen ST. Structure and function of mammalian cilia. His tochemist Cell Biol. 2008;129:687-93.

58. Eliasson R, Mossberg B, Camner P, Afzelius BA. The immotile-cilia syndrome. A congenital ciliary abnormality as an etiologic factor in chronic airway infections and male sterility. N Engl J Med. 1977;297:1-6.

59. Ibañez-Tallon I, Pagenstecher A, Fliegauf M, Olbrich H, Kispert A, Ketelsen U-P, et al. Dysfunction of axonemal dynein heavy chain Mdnah5 inhibits ependymal flow and reveals a novel mechanism for hydrocephalus formation. Hum Mol Genet. 2004:13:2133-41.

60. Nonaka S, Tanaka Y, Okada Y, Takeda S, Harada A, Kanai Y, et al. Randomization of left-right asymmetry due to loss of nodal cilia generating leftward flow of extraembryonic fluid in mice lacking KIF3B motor protein. Cell. 1998;95:829-37.

61. Pazour GJ, Dickert BL, Vucica Y, Seeley ES, Rosenbaum JL, Witman $\mathrm{GB}$, et al. Chlamydomonas IFT88 and its mouse homologue, polycystic kidney disease gene $\operatorname{tg} 737$, are required for assembly of cilia and flagella. J Cell Biol. 2000;151:709-18.

62. Salomon R, Saunier S, Niaudet P. Nephronophthisis. Pediatr Nephrol. 2009;24:2333-44.

63. Zaghloul NA, Katsanis N. Functional modules, mutational load and human genetic disease. Trends Genet: TIG. 2010;26:168-76

64. Swanhart LM, Cosentino CC, Diep CQ, Davidson AJ, De Caestecke M, Hukriede NA. Zebrafish kidney development: basic science to translational research. Birth Defects Res C Embryo Today. 2011:93:141-56.

65. Ali S, Champagne DL, Spaink HP, Richardson MK. Zebrafish embryos and larvae: a new generation of disease models and drug screens. Birth Defects Res C Embryo Today. 2011;93:115-33.

66. Lee H, Inselman AL, Kanungo J, Hansen DK. Alternative models in developmental toxicology. Syst Biol Reproductive Med. 2012;58:10-22.

67. Lessman CA. The developing zebrafish (Danio rerio): a vertebrate model for high-throughput screening of chemical libraries. Birth Defects Res C Embryo Today. 2011;93:268-80.

68. Peterson RT, Macrae C. Systematic approaches to toxicology in the zebrafish. Ann Rev Pharmacol Toxicol. 2012;52:433-53.

69. Konantz M, Balci TB, Hartwig UF, Dellaire G, André MC, Berman JN, et al. Zebrafish xenografts as a tool for in vivo studies on human cancer. Ann NY Acad Sci. 2012;1266:124-37.

70. Rodrigues FS, Yang X, Nikaido M, Liu Q, Kelsh RN. A simple, highly visual in vivo screen for anaplastic lymphoma kinase inhibitors. ACS Bio Chem. 2012:7:1968-74.

71. Mandrekar N, Thakur NL. Significance of the zebrafish model in the discovery of bioactive molecules from nature. Biotechnol Lett. 2009;31:171-9.

72. Sipes NS, Padilla S, Knudsen TB. Zebrafish-As an integrative model for twenty-first century toxicity testing. Birth Defects Res C Embryo Today. 2011;93:256-67.

73. Huang X, Nguyen AT, Li Z, Emelyanov A, Parinov S, Gong Z. One step forward: the use of transgenic zebrafish tumor model in drug screens. 
Birth defects research. Part C, Embryo Today: Rev. 2011;93:173-81.

74. De Esch C, Slieker R, Wolterbeek A, Woutersen R, De Groot D. Zebrafish as potential model for developmental neurotoxicity testing: a mini review. Neurotoxicol Teratol. 2012;34:545-53.
75. Callaway E. Zebrafish genome helps in hunt for treatments. Nature. 2013 Apr 17; doi:10.1038/nature.2013.12821. [Consulted May 2013]. Available at: http://www.nature.com/news/zebrafish-genome-helps-inhunt-for-treatments-1.12821. 